\title{
Motivation: The Key to Improve Students’ Outcomes
}

Ha Vo

Le Quy Don Gifted High School, Quang Tri Province

\begin{abstract}
Most students in Vietnam have been exposed to English since the third grade. However, their outcomes are still limited due to a lack of motivation to study English. This presentation will suggest a number of policies to improve student achievement.
\end{abstract}

\section{Session Description}

How to motivate students to learn English and participate in classroom activities enthusiastically in the context of Vietnam is a significant concern among EFL teachers. This presentation reports on different ways of motivating students which definitely influence the teaching and learning process. However, "motivation is, without question, the most complex and challenging issue facing teachers today” (Scheidecker \& Freeman, 1999, p. 116). As cited in Thanasoulas (2002), "Dornyei (2001) notes, teacher skills in motivating learners should be seen as central to teaching" (p. 1). Also as cited in Thanasoulas (2002), "[e]ven though there have been a lot of education-oriented publications providing taxonomies of classroom-specific motives, they fall short of offering an efficient guide to all or most practitioners" (p. 1). To this point, the presenter, therefore, focuses on analyzing what affects students' interest in learning English more in depth and then suggests what teachers should do to stimulate them, which can undoubtedly help students with their learning accomplishments. The presentation begins with a brief general description of the reality of studying English as a foreign language in Vietnam. Then the presenter presents methods for collecting student feedback regarding their needs for English, and strengths and weaknesses. The presenter then suggests a number of strategies based on the information collected to improve the students' inspiration to learn English. Finally, the presenter discusses ideas about how to maintain students' long-term motivation. This presentation will be useful to current EFL teachers and to those who would like to be future English teachers in Vietnam as well. 


\section{References}

Scheidecker, D. and Freeman, W. (1999). Bringing out the best in students: How legendary teachers motivate kids. London: SAGE.

Thanasoulas, D. (2002, November). Motivation and Motivating in the Foreign Language Classroom. Retrieved from http://iteslj.org/Articles/Thanasoulas-Motivation.html. 